\title{
ALLOZYME VARIATION IN THE BROWN TROUT (SALMO TRUTTA L.): SINGLE LOCUS AND JOINT SEGREGATION INHERITANCE STUDIES
}

\author{
JOHN B. TAGGART AND ANDREW FERGUSON \\ Department of Zoology, The Queen's University of Belfast, Belfast BT7 INN, N. Ireland \\ Received 7.xi.83
}

\begin{abstract}
SUMMARY
Inheritance studies have confirmed the genetic interpretations of previously described polymorphisms, detected by starch gel electrophoresis, at 13 enzyme coding loci in the brown trout. Biopsy techniques facilitated the prior typing of broodstock, enabling the careful planning of informative matings. Joint segregation analyses of 49 different pairwise comparisons of loci revealed apparent non-random assortment between four pairs; ${ }_{s}$ Aat-1,2 and ${ }_{s}$ Mdh-2, ${ }_{s} A a t-1,2$ and Ck-2, ${ }_{s}$ Mdh-3,4 and Pgi-2, Dia and Pgi-2. In conjunction with published data, these results indicate conservatism of the ${ }_{s} \mathrm{Aat}-1,2 /{ }_{\mathrm{s}} \mathrm{Mdh}-2$ linkage association between Salmo and Salvelinus.
\end{abstract}

\section{INTRODUCTION}

Fish of the family Salmonidae (salmon, trout, charr, whitefish, grayling) are considered to be a tetraploid derivative lineage as compared to their close diploid relatives, e.g., smelts and herring (Ohno et al., 1969; Ohno, 1970; Schmidtke et al., 1976a, b; May, 1980). As such they have recently commanded considerable attention as research organisms in the study of evolution by gene duplication. The recognition of the economic and recreational value of many of these salmonid species has been the main impetus, for many years, for extensive scientific investigations into their population biology and management of stocks. Both lines of enquiry have greatly benefitted from the development and refinement of gel electrophoresis as a relatively convenient and powerful technique for the indirect assessment of variability at a random sample of structural gene loci (Ferguson, 1980).

The sound application of electrophoretic methodology relies on a full understanding of the underlying genetic basis of observed banding patterns. However, the extensive gene duplication still extant among salmonid species, estimated at approximately 50 per cent (Allendorf $e t$ al., 1975), leads to the occurrence of complex zymograms for most enzymes. Correct interpretation may be further confounded by the presence of non-genetic electrophoretic variation, a not uncommon phenomenon which may be due to a variety of factors (e.g., Amend and Smith, 1974; Allendorf and Utter, 1979; Taggart et al., 1981a). Thus, verification of the genetic bases of banding patterns through inheritance studies is especially important for the proper appraisal of electrophoretic data relating to salmonids (Allendorf and Phelps, 1981). Many such studies have been undertaken, though these have been mainly restricted to native North American species (e.g., Bailey et al., 1970; Allendorf and Utter, 1973; Ropers et al., 1973; May et al., 1975; Reinitz, 1977; Stoneking et al., 1979, 1981). 
In studying the present status of salmonid genomes particular attention has been focused on those duplicated loci which share electrophoretically identical alleles and on the linkage relationships among loci. Current evidence indicates that the process of diploidisation is not yet complete. While all inheritance studies to date have demonstrated disomic inheritance only, occasional unexpected progeny phenotypes have been detected (e.g., Wright et al., 1980). Furthermore, linkage studies have revealed an unusual genetic phenomenon, unique to salmonids, which has been termed "pseudolinkage" (Davisson et al., 1973). This is often characterised by an excess of non-parental types among progeny of backcrosses involving males heterozygous for certain loci. It has never been observed for similar crosses involving informative (doubly heterozygous) females. This phenomenon is more prevalent in genomes from two diverse sources (e.g., inter-specific hybrids) and always involves (directly or indirectly) duplicate loci. Pseudolinkage has been detected for both Salmo and Salvelinus. (See May (1980); May et al., (1980); Wright et al., (1980); for detailed treatment). These forms of aberrant segregation are considered to reflect a degree of "residual tetrasomy" (May et al., 1979b) within the salmonid genome.

A more thorough understanding of the mechanism behind the evolutionary restructuring of the salmonid genome following tetraploidy should be evident through identification of linkage homologies among species. An essential prerequisite for linkage analyses is the presence of allelic polymorphism at both loci under consideration. Only in individuals heterozygous for both loci, where the chromosomes of a homologous pair carrying a polymorphic locus are uniquely marked by different alleles, is it possible to study the joint segregation of loci in relation to specific (i.e., same or different) chromosomes at meiosis. To date, studies on the brook trout (Salvelinus fontinalis Mitchill), lake trout (Salvelinus namaycush Walbaum) and their interspecific fertile $F_{1}$ hybrid, splake trout, have yielded the most information on salmonid enzyme loci linkage relationships. This is directly attributable to the ideal genetic composition of the splake trout as an informative parent in joint segregation analyses, being heterozygous for a large number of loci and of known linkage phase, and readily backcrossed with either (homozygous) parental species. As a result more than 300 different pairwise comparisons of enzyme loci for joint segregation in Salvelinus have been reported (summarised by May et al., 1980). In addition much more limited studies (primarily restricted by the number of polymorphic loci) have been reported for other salmonid species; e.g., rainbow trout, Salmo gairdneri Richardson (Allendorf, 1975; May et al., 1982); cutthroat trout, Salmo clarki Richardson (Allendorf and Utter, 1976); Oncorhynchus spp. (Aspinwall, 1974; May et al., 1975); lake whitefish, Coregonus clupeaformis Mitchill (Clayton et al., 1973). Many of these and other studies are summarised by May et al., $(1979 b)$. The combined data suggest that there is a high degree of linkage group conservatism among genera (May et al., 1982).

Electrophoretic studies of the brown trout (Salmo trutta L.) have revealed putative genetic variation involving, at least, 17 enzyme coding loci (Engel et al., 1971; Allendorf et al., 1976, 1977; May et al., 1979a; Ståhl, 1980; Taggart et al., 1981 a). The observed allozymic variation has been primarily employed as a means of delineating both natural and hatchery stocks (e.g., Ryman et al., 1979; Ryman and Ståhl, 1980, 1981; Ferguson and Mason, 
1981). To date, however, only very limited inheritance studies have been undertaken to confirm the genetic bases of the observed electrophoretic variation. For Swedish stocks, simple Mendelian inheritance has been reported for a polymorphism at Agp-2 (variant allele Agp-2 (50); nomenclature is equivalent to G3p-2 in this paper) by Ståhl and Ryman, 1982). Furthermore, confirmation of the genetic basis of polymorphism at Ldh-1, involving a variant allele Ldh-l(n) is cited by Ståhl (1980). Allelic variants ${ }_{s} \operatorname{Mdh}-1(\phi)$, ${ }_{s} M d h-2(152), \operatorname{Dia}(90)$ and G3p-1(50) (nomenclature is equivalent to G3p-2 in this paper), present in North American hatchery stocks have also been confirmed through inheritance data (May et al., 1979a; May, 1980). In these latter studies joint segregation analyses between ${ }_{\mathrm{s}} \mathrm{Mdh}-1$ and ${ }_{s} \mathrm{Mdh}-2$, ${ }_{s} \mathrm{Mdh}-1$ and G3p-1, ${ }_{\mathrm{s}} \mathrm{Mdh}-2$ and G3p-1, and Dia and ${ }_{\mathrm{s}} \mathrm{Mdh}-2$ were also undertaken. Random association between loci was recorded in each case. Since the brown trout possesses relatively few (11) metacentric chromosomes, the investigation of linkage associations within this species is considered to be of particular importance in assigning salmonid linkage groups to single chromosome arms (May et al., 1980). Comparable data to ours is presented by Guyomard and Krieg (1983).

This paper reports on the verification, through inheritance studies, of the genetic bases of electrophoretic variation present within natural and hatchery populations of brown trout, previously described by Taggart et al., (1981a). Results of joint segregation analyses between loci are also presented and discussed.

\section{Materials AND Methods}

(i) Matings

Specific crosses were performed in November and December 1980 and 1981. Twenty-five $2+$ year old mature brown trout (11 $\left.\delta^{*}: 149\right)$ and hatchery facilities were provided at Movanagher Fish Farm. Previous electrophoretic analyses of a number of Irish brown trout populations (Taggart, 1981) had shown this domesticated stock to be polymorphic at all but one (Ldh-1) of the known polymorphic loci present in Irish populations and thus was ideal for this investigation. Additional broodstock were also obtained from native brown trout populations of L. Melvin (10ð: 15\%) and L. Erne ( $7 \delta^{\prime}$ 3\%) Co. Fermanagh.

With limited hatchery facilities available the typing of broodstock prior to spawning and comprehensive planning of informative matings was required. Adapting the methods of Uthe (1971), skeletal muscle and liver samples were taken from anaesthetised fish using an unmodified Silverman liver biopsy needle. This was undertaken three to fourteen days prior to spawning, each fish being identified by a unique combination of "Panjet" dye markings (Hart and Pitcher, 1969). All polymorphic loci, with the exception of Ldh-5 (present only in neural and retinal tissues), were typable from extracts of these two tissues. This technique permitted the option to retain fish (usually males) of uncommon genotypes for future matings. On completion of selected matings all broodstock were sacrificed and retyped in conventional manner. Without exception typing was in accord with that previously derived from the biopsy samples. No mortalities arose prior to spawning. Informative crosses for Ldh- 5 were performed by random matings 
between two stocks (Movanagher and Erne) known to have contrasting frequencies for the variant $\mathrm{Ldh}-5(105)$ allele $(0.08$ and 0.91$)$. Throughout the planning and execution of informative crosses, priority was given to single locus segregation investigations.

Individual crosses of 500-1000 eggs each from a single male and female were made, sealed in separate containers and incubated in river water. Some duplicate crosses were successfully reared at the laboratory using mains tap water. A combination of factors including parental sterility and fungal disease reduced the initial 50 crosses to 34 by the time of screening. Due to the restriction on rearing facilities, typing of most of the resultant progeny had to be accomplished at the sac fry stage of development. However, three crosses were maintained to the four weeks fed fry stage to enable retrieval of liver tissue and subsequent screening for ${ }_{s}$ Aat-4. In general, sac fry extracts gave satisfactory resolution for all other polymorphic loci.

\section{(ii) Electrophoresis}

Depending on the tissue expression of the specific loci under investigation (see Taggart et al., 1981a), either head or whole body samples (minus yolk sac) were prepared. This enabled confident typing of all polymorphic loci with the exception of liver specific ${ }_{s}$ Aat-4. Excision of eye samples alone provided better resolution for Ldh-5 zymograms and was preferentially used. Some difficulty was encountered with MDH due to persistence of maternal allozymes in progeny extracts up to three days post hatching.

Addition of $5-15 \mu \mathrm{l}$ of $0.01 \mathrm{M}$ Tris- $\mathrm{HCl}, p \mathrm{H} \mathrm{7.4}$, to both biopsy and progeny samples (50-100 $\mu$ l for sacrificed adult tissue samples), followed by an overnight freeze-thaw cycle, was found to be sufficient preparation for routine screening of polymorphic enzyme systems. Tissue extracts were subjected to horizontal starch gel electrophoresis and stained for known polymorphic enzyme systems. The enzymes examined and their abbreviations are listed in table 1 . The detailed electrophoretic methodology, tissue expression and descriptions of polymorphic enzyme systems, including photographs, are given elsewhere (Taggart et al., 1981a).

\section{(iii) Nomenclature}

An extension of the nomenclature proposed by Allendorf and Utter (1979), involving mobility defined alleles, is used as described by Taggart et al., $(1981 a)$. However, an additional modification is implemented in this paper, conforming with most recent salmonid electrophoresis publications (Allendorf et al., 1982; May et al., 1982). A capitalised abbreviation still denotes each protein (e.g., DIA) but when referring to the encoding locus only the first letter is capitalised (e.g., Dia), whereas previously the same abbreviation, italicised, referred to the locus. It should be noted that the terminology Xyz-1,2 refers to duplicate loci sharing common alleles where it is not known to which locus variation is attributable, while reference to multiple loci takes the form Xyz-(1,2,3).

Muscle specific loci were formerly denoted as Ck-(1,2) (Taggart et al., $1981 a$ ) but this publication overlooked the existence of a stomach-specific CK locus (Perriard et al., 1972; Taggart et al., 1981 b) the enzyme product of which is slower in mobility to those produced by the muscle specific CK loci. This has necessitated a revision of nomenclature for this enzyme with 
TABLE

Summary of allelic variants recorded for known polymorphic enzyme loci in British and Irish brown trout populations

\begin{tabular}{|c|c|c|c|c|}
\hline Enzyme & Abbrev. & E.C. No. & Locus & $\begin{array}{l}\text { Variant } \\
\text { allele }\end{array}$ \\
\hline Aspartate aminotransferase & AAT & 2.6.1.1 & $\begin{array}{l}{ }_{\mathrm{s}}^{\text {Aat-1,2 }} \text { Aat-1,2 } \\
{ }_{\mathrm{s}} \text { Aat } 1,4 \\
\text { Aat } 4\end{array}$ & $\begin{array}{r}140^{*} \\
45^{*} \\
74^{*}\end{array}$ \\
\hline Creatine kinase & CK & 2.7.3.2 & $\begin{array}{r}\mathrm{Ck}-2 \\
\mathrm{Ck}-2\end{array}$ & $\begin{array}{l}115^{*} \\
75\end{array}$ \\
\hline Diaphorase & DIA & 1.6.2.2 & $\begin{array}{l}\text { Dia } \\
\text { Dia }\end{array}$ & $\begin{array}{r}120^{*} \\
90^{*}\end{array}$ \\
\hline $\begin{array}{l}\text { Glycerol-3-phosphate } \\
\text { dehydrogenase }\end{array}$ & G3P & 1.1 .1 .8 & $\begin{array}{l}\text { G3p-2 } \\
\text { G3p-2 } \\
\text { G3p-2 }\end{array}$ & $\begin{array}{c}120 \\
50^{*} \\
30\end{array}$ \\
\hline $\begin{array}{l}\text { Isocitrate dehydrogenase } \\
\text { (NADP-dependent) }\end{array}$ & IDH & 1.1.1.42 & $\begin{array}{l}\text { Idh-1 } \\
\text { I Idh-1 } \\
\text { Iddh-2 }\end{array}$ & $\begin{array}{c}160^{*} \\
10 \\
130^{*}\end{array}$ \\
\hline Lactate dehydrogenase & LDH & 1.1.1.27 & $\begin{array}{l}\text { Ldh-1 } \\
\text { Ldh-5 }\end{array}$ & $\begin{array}{l}\mathrm{n}^{* * *} \\
105^{*}\end{array}$ \\
\hline Malate dehydrogenase & MDH & 1.1.1.37 & $\begin{array}{l}\text { sdh-2 } \\
{ }_{s} \text { Mdh-3,4 } \\
\text { sMdh-3,4 } \\
{ }_{s} \text { Mdh-3,4 } \\
{ }_{3} \text { Mdh-3,4 }\end{array}$ & $\begin{array}{l}152^{*} \\
134 \\
125 \\
85 \\
75^{*}\end{array}$ \\
\hline $\begin{array}{l}\text { Mannose phosphate isomerase } \\
\text { Phosphoglucose isomerase }\end{array}$ & $\begin{array}{l}\text { MPI } \\
\text { PGI }\end{array}$ & $\begin{array}{l}5.3 .1 .8 \\
5.3 .1 .9\end{array}$ & $\begin{array}{l}\text { Mpi } \\
\text { Pgi-2 } \\
\text { Pgi-2 } \\
\text { Pgi-2 } \\
\text { Pgi-3 } \\
\text { Pgi-3 }\end{array}$ & $\begin{array}{c}90 \\
135^{*} \\
122 \\
65 \\
110^{*} \\
80\end{array}$ \\
\hline
\end{tabular}

* Verified through inheritance studies, this investigation.

** Null allele; status and inheritance verified by Henry (1984).

muscle specific loci being renamed $\mathrm{Ck}-(2,3), \mathrm{Ck}-2$ being the polymorphic locus in brown trout.

\section{(iv) Joint segregation statistics}

Conforming with previous joint segregation analyses of salmonids the mobility defined alleles at the two loci being examined were redesignated in the classical form $A, A^{\prime}$ and $B, B^{\prime}$ and the symbols and statistics of Mather (1951) were applied. Both the testcross, $\mathrm{AABB} \times \mathrm{AA}^{\prime} \mathrm{BB}^{\prime}$, and single backcross $\mathrm{AABB}^{\prime} \times \mathrm{AA}^{\prime} \mathrm{BB}^{\prime}$ revealed progeny genotypes indicative of the respective gametic contribution of the two parents. In the latter case the heterozygous progeny for the locus heterozygous in both parents (i.e., $\mathrm{BB}^{\prime}$ ) were excluded, as the respective parental contributions could not be deduced in these individuals (May et al., 1979b). The symbols and analysis were therefore as follows:

$$
\begin{array}{lcc} 
& \text { Test cross } & \text { Single backcross } \\
a_{1}=\text { observed progeny } & \text { AABB } & \text { AABB } \\
a_{2}=\text { observed progeny } & \text { AABB' }^{\prime} & \text { AAB' }^{\prime}
\end{array}
$$




$$
\begin{aligned}
& a_{3}=\text { observed progeny } \\
& \text { Test cross } \\
& a_{4}=\text { observed progeny } \\
& \text { AA'BB } \\
& \text { Single backcross } \\
& \mathrm{AA}^{\prime} \mathrm{BB}^{\prime} \\
& \text { AA'BB } \\
& N=\text { total informative progeny }=a_{1}+a_{2}+a_{3}+a_{4} \\
& =\left(a_{1}+a_{2}-a_{3}-a_{4}\right)^{2} / N \quad(\text { d.f. }=1)
\end{aligned}
$$

$\chi_{B}^{2}=$ test for departure from $1: 1$ segregation at the B locus (test cross only)

$$
=\left(a_{1}-a_{2}+a_{3}-a_{4}\right)^{2} / N \quad(\text { d.f. }=1)
$$

(for the single backcross, more accurate values for segregation at both loci are obtained from testing all progeny, not just informative progeny, $N$. For the B locus test for departure from $1: 2: 1$ segregation, d.f. $=2$, is required)

$$
\begin{aligned}
\chi_{\mathrm{L}}^{2}= & \text { test for departure from independent assortment of the two loci } \\
= & \left(a_{1}-a_{2}-a_{3}+a_{4}\right)^{2} / N \quad(\mathrm{~d} . \mathrm{f} .=1) \\
r= & \text { fraction of non-parental genotypes (assuming the largest class, } \\
& \left(a_{1}+a_{4}\right) \text { or }\left(a_{2}+a_{3}\right) \text { represents the parental genotypes when } \\
& \text { linkage phase is unknown) } \\
= & \left(a_{2}+a_{3}\right) / N \text { or }\left(a_{1}+a_{4}\right) / N \text { respectively } \\
\text { s.e. = } & \text { standard error of } r=\sqrt{r(1-r) / N}
\end{aligned}
$$

The classic form of nomenclature used is such that a parent heterozygous for a third allele at a locus is still designated as homozygous (i.e., AA or $\mathrm{BB}$ ) with respect to the informative double heterozygous parent as distinction of all parental contributions from progeny genotypes remains unimpeded. Furthermore, a homozygous individual (AA or BB) may be homozygous with regard to any allele (common or variant), the heterozygote $\left(\mathrm{AA}^{\prime}\right)$ having a single copy of this allele.

In excess of 100 progeny for each cross were electrophoretically screened. Therefore, for a single backcross in which approximately 50 per cent of the progeny (heterozygous BB' $^{\prime}$ ) are excluded from the joint segregation analysis, sufficient informative progeny were scored. The lowest informative sample size analysed consisted of 44 individuals.

\section{Results}

\section{(i) Single locus segregation}

Screening of the potential broodstock revealed variation at 12 of the 13 definitive polymorphic loci described by Taggart et al., (1981a), though only 13 of the 20 variant alleles reported in that study were present. Informative crosses involving all these loci were accomplished and the resultant progeny successfully screened. Subsequent studies in this Laboratory (Ferguson and Fleming, 1983; unpublished data) have revealed additional allelic variants at these polymorphic loci in other British and Irish brown trout populations. These are included in an updated list of allelic 
variants observed by this group, table 1 , those alleles verified through inheritance studies being indicated.

The single locus segregation data are presented in tables 2 to 6 . In these tables where replicates of a particular type of cross have been accomplished, only the overall pooled results are given. However, all crosses differing significantly from Mendelian expectations are individually mentioned in the text. The segregation data involving the duplicated loci ${ }_{\mathrm{s}}$ Aat-1,2, $\mathrm{sdh}$ 3,4 and $\mathrm{Ck}-(2,3)$ are of particular interest and thus are detailed below in full. In the case of ${ }_{s} A a t-1,2$ and ${ }_{s}$ Mdh-3,4 it is appropriate for clarity to redesignate the mobility defined alleles in the less cumbersome classical form $\mathbf{A}, \mathbf{A}^{\prime}$ and $\mathbf{A}^{\prime \prime}$.

\section{TABLE 2}

Pooled results of informative crosses for ${ }_{s}$ Aat-1,2, involving parents with only a single dose of a variant allele. This includes G-test analysis for Mendelian segregation of alleles. Alleles are redefined ${ }^{a}$ in classical form to aid interpretation and table compilation

\begin{tabular}{|c|c|c|c|c|c|c|c|c|c|}
\hline \multirow{2}{*}{$\begin{array}{l}\text { No. of } \\
\text { crosses }\end{array}$} & \multirow{2}{*}{$\begin{array}{l}\text { Parental } \\
\text { male }\end{array}$} & \multirow{2}{*}{$\begin{array}{l}\text { Genotype } \\
\text { female }\end{array}$} & \multirow{2}{*}{$\begin{array}{l}\text { Total } \\
\text { progeny }\end{array}$} & \multicolumn{4}{|c|}{$\begin{array}{c}\text { Observed progeny genotypes } \\
\text { (expected) }\end{array}$} & \multirow{2}{*}{$\begin{array}{c}G \\
\text { (d.f.) }\end{array}$} & \multirow[b]{2}{*}{$P$} \\
\hline & & & & AAAA & $\mathrm{AAAA}^{\prime}$ & $\mathrm{AAA}^{\prime} \mathrm{A}^{\prime}$ & AAAA" & & \\
\hline 5 & $\mathrm{AAAA}^{\prime}$ & AAAA & 523 & $\begin{array}{l}263 \\
(261 \cdot 5)\end{array}$ & $\begin{array}{l}260 \\
(261 \cdot 5)\end{array}$ & - & - & $\begin{array}{l}0.017 \\
(1)\end{array}$ & $>0.8$ \\
\hline 4 & AAAA & $\mathrm{AAAA}^{\prime}$ & 419 & $\begin{array}{l}221 \\
(209 \cdot 5)\end{array}$ & $\begin{array}{c}198 \\
(209 \cdot 5)\end{array}$ & - & - & $\begin{array}{l}1.263 \\
\text { (1) }\end{array}$ & $>0.2$ \\
\hline 3 & $\mathrm{AAAA}^{\prime}$ & $\mathrm{AAAA}^{\prime}$ & 293 & $\begin{array}{l}80 \\
(73 \cdot 25)\end{array}$ & $\begin{array}{l}133 \\
(146 \cdot 5)\end{array}$ & $\begin{array}{l}80 \\
(73 \cdot 25)\end{array}$ & - & $\begin{array}{l}2 \cdot 492 \\
(2)\end{array}$ & $>0.2$ \\
\hline 1 & $\mathrm{AAAA}^{\prime \prime}$ & AAAA & 105 & $\begin{array}{l}54 \\
(52 \cdot 5)\end{array}$ & - & - & $\begin{array}{l}51 \\
(52 \cdot 5)\end{array}$ & $\begin{array}{l}0.086 \\
(1)\end{array}$ & $>0.7$ \\
\hline
\end{tabular}

"A $=$ " 100 " allele.

$A^{\prime}=" 140 "$ allele.

$A^{\prime \prime}=" 45 "$ allele.

(a) ${ }_{s}$ Aat $-1,2$

Three alleles, sat-1,2(100,140,45) (hereafter $A, A^{\prime}$ and $A^{\prime \prime}$ respectively) have been found to segregate for ${ }_{s}$ Aat-1,2 in Irish brown trout (Taggart $e t$ al., $1981 a$ ). Inheritance studies involving all three alleles were accomplished during this investigation. Table 2 summarises results from informative crosses involving parents possessing only a single dose of a variant allele. All four classes of crosses performed fitted a model of simple Mendelian inheritance. A single cross (A22) of type $\mathrm{AAAA}^{\prime} \times \mathrm{AAAA}^{\prime}$ showed a statistically significant deficit $\left(G_{2}=6.208, P<0.05\right)$ of $\mathrm{AAAA}^{\prime}$ (heterozygous) progeny.

Unlike the above crosses, where single doses of a variant allele segregate $1: 1\left(A: A^{\prime}\right)$ under both a disomic and tetrasomic model of inheritance, segregation of alleles from individuals with a double dose of a variant allele provides sufficient evidence to distinguish between these two models (Allendorf et al., 1975). Thus, under a disomic model of inheritance, an individual of genotype $\mathrm{AAA}^{\prime} \mathrm{A}^{\prime}$ will segregate for the gametic genotypes $\mathrm{AA}: \mathrm{AA}^{\prime}: \mathrm{A}^{\prime} \mathrm{A}^{\prime}$ in the ratio $1: 2: 1$ if doubly heterozygous (i.e. $\mathbf{A A}^{\prime} / \mathbf{A A}^{\prime}$ ) or $0: 1: 0$ if doubly 
homozygous (i.e., $\mathrm{AA} / \mathrm{A}^{\prime} \mathrm{A}^{\prime}$ ). Under a tetrasomic model a gametic segregation ratio between $1: 4: 1$ and $3: 8: 3$ is expected, depending on how close to the centromere the locus is (Allendorf and Utter, 1976). Test crossing such individuals with others possessing a single banded phenotype, i.e., AAAA, enables the direct assessment of gametic segregation through progeny screening. Additional crosses, other than test crosses, which permit the deduction of gametic segregation from observed progeny phenotypes may also be employed to discriminate between disomic and tetrasomic inheritahce models. In order to prove disomic inheritance conclusively, both double homozygote $\left(\mathrm{AA} / \mathrm{A}^{\prime} \mathrm{A}^{\prime}\right)$ and double heterozygote $\left(\mathrm{AA}^{\prime} / \mathrm{AA}^{\prime}\right.$ ) segregation should be observed, to avoid any confounding problems caused by linkage (Allendorf and Utter, 1976).

Data from informative crosses involving parents having, at least, a double dose of variant alleles are presented in table 3. For all 11 crosses the results best fit the model of disomic inheritance. Furthermore, both a double heterozygous cross (A2) and double homozygous crosses (the rest) were tested thus fulfilling a further condition for the positive establishment of disomic inheritance. Note that a single anomalous progeny phenotype was observed (cross A23). Similar occurrences have been noted in other studies of duplicate loci in salmonids (e.g., Clayton et al., 1975; Wright et al., 1980). It is also evident from the data (cross A2) that, at least, one of the variant alleles, ${ }_{s}$ Aat-1,2(140) segregates at both loci. Of a total of 24 Aat-1,2 crosses examined, two (A22-mentioned above, and A49-table 3) did not segregate according to simple Mendelian inheritance.

\section{(b) ${ }_{s} M d h-3,4$}

Four variant alleles, ${ }_{s} \mathrm{Mdh}-3,4(134,125,85,75)$ have been previously described for Irish brown trout populations (Taggart et al., 1981a). The genetic validity of the latter two alleles, ${ }_{s} \mathrm{Mdh}-3,4(85,75)$ was particularly questioned as population data indicated the occasional presence of additional non-genetic variation of similar mobility to the presumed ${ }_{\mathrm{s}} \mathrm{Mdh}$ $3,4(85,75)$ allelic products.

Variation at ${ }_{\mathrm{s}} \mathrm{Mdh}-3,4$ in the potential broodstock was confined to the products of the presumed ${ }_{\mathrm{s}} \mathrm{Mdh}-3,4(75)$ allele, hereafter termed $\mathrm{A}^{\prime}$. The segregation data for informative crosses are summarised in table 4. Assuming the single heterozygote ( $\left.\mathrm{AAAA}^{\prime}\right)$ and double heterozygote-or double homozygote-( $\mathrm{AAA}^{\prime} \mathrm{A}^{\prime}$ ) cannot unequivocally be distinguished (see below), all types of crosses (and replicates) were found to segregate in Mendelian fashion, thus giving positive evidence for the existence of the ${ }_{s} \mathrm{Mdh}-3,4(75)$ allele. The inability to distinguish between these two genotypes was apparently not confined to the progeny typing, the observed anomalous segregation of the two crosses (table 4) being most easily accounted for by postulating the mistyping of $\mathrm{AAA}^{\prime} \mathrm{A}^{\prime}$ broodstock as $\mathrm{AAAA}^{\prime}$ phenotypes. However, resolution of sac fry extracts for ${ }_{s} \mathrm{Mdh}-3,4$ was found to be consistently poorer than that achieved for adult trout and prevented accurate discrimination between presumed $9: 6: 1$ and $1: 2: 1$ phenotypes in all crosses examined. As the two genotypes $\mathrm{AAAA}^{\prime}$ and $\mathrm{AAA}^{\prime} \mathrm{A}^{\prime}$ proved indistinguishable, the mode of inheritance, i.e., disomic or tetrasomic, could not be investigated for these duplicate loci. 


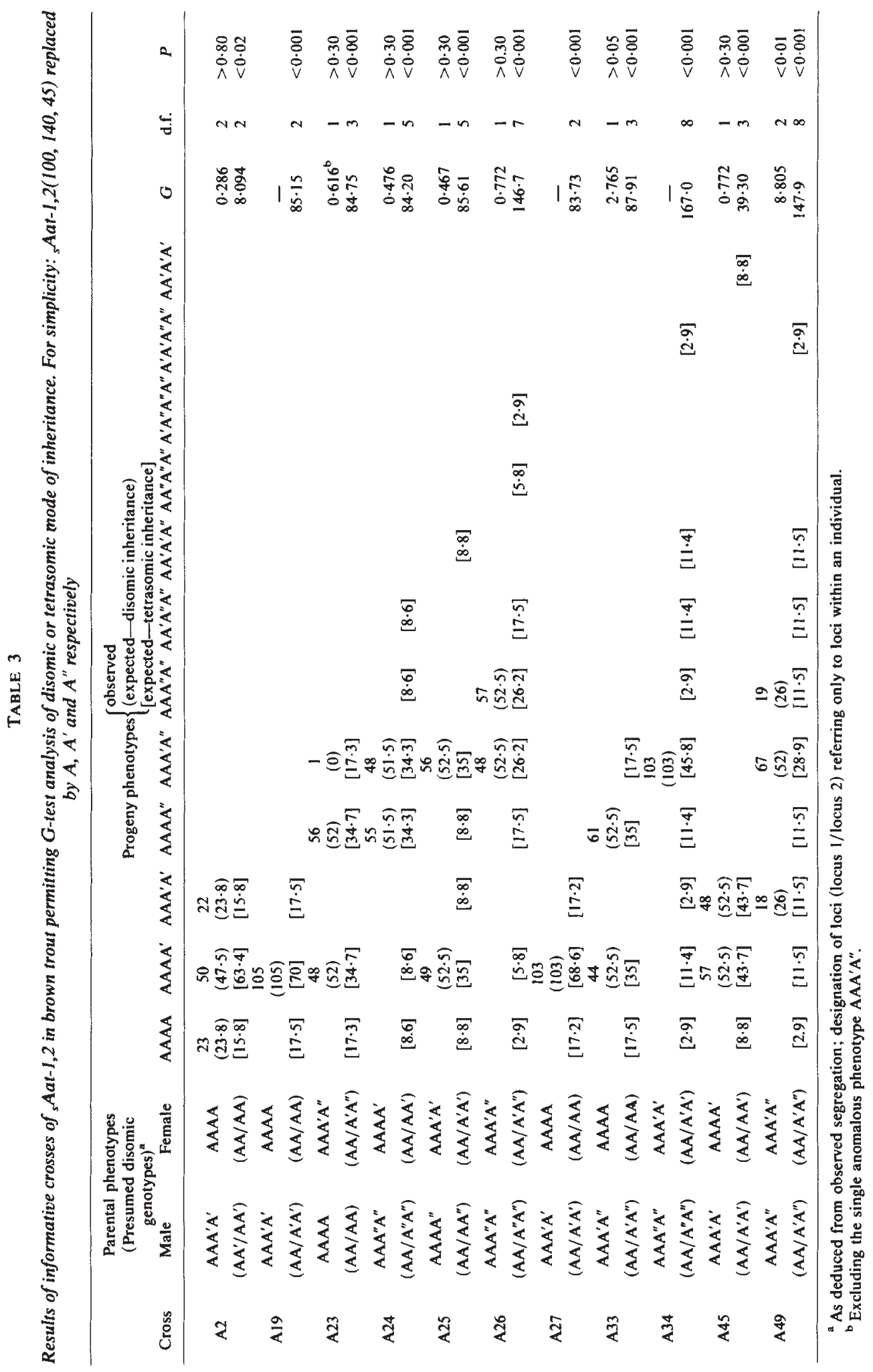


TABLE 4

Pooled results of informative crosses for ${ }_{s} M d h-3,4$ including G-test analysis for Mendelian segregation of alleles. Alleles are redefined ${ }^{2}$ in classical form to aid interpretation and table compilation

\begin{tabular}{|c|c|c|c|c|c|c|c|}
\hline \multirow[b]{2}{*}{$\begin{array}{l}\text { No. of } \\
\text { crosses }\end{array}$} & \multicolumn{2}{|c|}{ Parental genotype } & \multirow[b]{2}{*}{$\begin{array}{c}\text { Total } \\
\text { progeny }\end{array}$} & \multicolumn{2}{|c|}{$\begin{array}{l}\text { Observed progeny } \\
\text { genotypes } \\
\text { (expected) }\end{array}$} & \multirow[b]{2}{*}{$\begin{array}{c}G \\
\text { (d.f.) }\end{array}$} & \multirow[b]{2}{*}{$P$} \\
\hline & Male & Female & & AAAA & $\begin{array}{l}\mathrm{AAAA}^{\prime}+ \\
\mathrm{AAA}^{\prime} \mathrm{A}^{\prime \mathrm{b}}\end{array}$ & & \\
\hline 7 & AAAA $^{\prime}$ & AAAA & 729 & $\begin{array}{c}355 \\
(364 \cdot 5)\end{array}$ & $\begin{array}{c}374 \\
(364 \cdot 5)\end{array}$ & $\begin{array}{l}0.495 \\
(1)\end{array}$ & $>0.3$ \\
\hline 3 & AAAA & $\mathrm{AAAA}^{\prime}$ & 315 & $\begin{array}{c}157 \\
(157 \cdot 5)\end{array}$ & $\begin{array}{c}158 \\
(157 \cdot 5)\end{array}$ & $\begin{array}{l}0.003 \\
(1)\end{array}$ & $>0.9$ \\
\hline 2 & AAAA $^{\prime}$ & AAAA $^{\prime}$ & 210 & $\begin{array}{c}46 \\
(52 \cdot 5)\end{array}$ & $\begin{array}{l}164 \\
(157 \cdot 5)\end{array}$ & $\begin{array}{l}1 \cdot 105 \\
(1)\end{array}$ & $>0.2$ \\
\hline 2 & $\begin{array}{c}\text { AAAA' }^{\prime} \\
\left(\text { AAAA' }^{\prime}\right)\end{array}$ & $\begin{array}{c}\mathrm{AAAA}^{\prime \mathrm{c}} \\
\left(\mathrm{AAA}^{\prime} \mathbf{A}^{\prime}\right)^{\mathrm{d}}\end{array}$ & 210 & - & $\begin{array}{l}210 \\
(210 \cdot 0)\end{array}$ & - & \\
\hline
\end{tabular}

a $A=$ " 100 " allele; $A^{\prime}=$ " 75 " allele.

'These genotypes are presumed indistinguishable.

${ }^{c}$ Presumed from gel phenotypes.

${ }^{d}$ Actual genotypes-from observed segregation (either parent, or both, may have a double dose of variant allele).

\section{(c) $C k-2$}

Differentiation of $\mathrm{Ck}-2(100 / 100)$ and Ck-2(100/115) phenotypes is based solely on different staining intensities of the observed three banded zymograms. (See Taggart et al., $1981 a$ for photograph). Segregation data for informative crosses involving Ck-2 variation are given in full in table 5 to illustrate the inaccuracy of distinguishing between the common homozygote and heterozygote patterns. Assuming that the Ck-2(100/100) and Ck-2(100/115) phenotypes are indistinguishable, the observed progeny segregation conforms with that expected from simple Mendelian inheritance. However, implicit in this explanation is the mistyping (Ck-2(100/115) as Ck-2(100/100)) of parental stock in four of the seven crosses detailed.

\section{(d) Other polymorphic loci}

All other loci examined, i.e., sAat-4, Dia, G3p-2, ${ }_{s}$ Idh-1, sIdh-2, Ldh-5, ${ }_{s}$ Mdh-2, Pgi-2 and Pgi-3, segregated in conformance with Mendelian expectations. The segregation data for these loci are summarised in table 6 , which illustrates both the number and type of cross examined and the number of progeny screened for each polymorphic locus. Only a single case of aberrant single locus segregation was noted within this data, involving one (cross A41, see table 9) of 16 informative crosses screened for ${ }_{s} \mathrm{Mdh}-2$ ( ${ }_{s}$ Mdh-2(100/152) $\times{ }_{s}$ Mdh-2(100/152); $\left.G_{2}=6.94, P<0.05\right)$.

The inheritance data presented for Dia includes verification of an allele $\mathrm{Dia}(120)$ not previously reported for the brown trout. The enzymatic product of this allele is of identical electrophoretic mobility to that of a known, storage induced, artefact band visualised for DIA zymograms (see Taggart et al., 1981a). 
TABle 5

Results of informative crosses for $C k$-2, including G-test analysis for Mendelian segregation of alleles

\begin{tabular}{|c|c|c|c|c|c|c|}
\hline \multirow[b]{3}{*}{ Cross } & \multirow{2}{*}{\multicolumn{2}{|c|}{$\begin{array}{l}\text { Parental genotype } \\
\text { presumed } \\
{\text { (actual })^{\mathrm{b}}}^{\mathrm{b}}\end{array}$}} & \multicolumn{2}{|c|}{$\begin{array}{l}\text { Observed progeny genotypes } \\
\text { (expected) }\end{array}$} & \multirow{3}{*}{$\underset{\text { (d.f.) }}{G}$} & \multirow[b]{3}{*}{$P$} \\
\hline & & & \multirow{2}{*}{$\begin{array}{l}100 / 100+ \\
100 / 115^{c}\end{array}$} & \multirow[b]{2}{*}{$115 / 115$} & & \\
\hline & Male & Female & & & & \\
\hline A22 & $\begin{array}{c}100 / 100 \\
(100 / 115)\end{array}$ & $\begin{array}{c}100 / 115 \\
(100 / 115)\end{array}$ & $\begin{array}{l}76 \\
(78.75)\end{array}$ & $\begin{array}{l}29 \\
(26 \cdot 25)\end{array}$ & $\begin{array}{l}0 \cdot 376 \\
(1)\end{array}$ & $>0.5$ \\
\hline A23 & $\begin{array}{l}115 / 115 \\
(115 / 115)\end{array}$ & $\begin{array}{c}100 / 115 \\
(100 / 115)\end{array}$ & $\begin{array}{l}60 \\
(52 \cdot 5)\end{array}$ & $\begin{array}{l}45 \\
(52 \cdot 5)\end{array}$ & $\begin{array}{l}2 \cdot 150 \\
\text { (1) }\end{array}$ & $>0.1$ \\
\hline A24 & $\begin{array}{l}115 / 115 \\
(115 / 115)\end{array}$ & $\begin{array}{l}115 / 115 \\
(115 / 115)\end{array}$ & - & $\begin{array}{l}105 \\
(105)\end{array}$ & - & \\
\hline A26 & $\begin{array}{l}115 / 115 \\
(115 / 115)\end{array}$ & $\begin{array}{c}100 / 100 \\
(100 / 100)\end{array}$ & $\begin{array}{c}105 \\
(105)\end{array}$ & - & - & \\
\hline $\mathrm{A} 42$ & $\begin{array}{c}100 / 100 \\
(100 / 115)\end{array}$ & $\begin{array}{c}100 / 100 \\
(100 / 115)\end{array}$ & $\begin{array}{l}82 \\
(78 \cdot 75)\end{array}$ & $\begin{array}{l}23 \\
(26 \cdot 25)\end{array}$ & $\begin{array}{l}0.552 \\
(1)\end{array}$ & $>0.3$ \\
\hline A44 & $\begin{array}{c}115 / 115 \\
(115 / 115)\end{array}$ & $\begin{array}{c}100 / 100 \\
(100 / 115)\end{array}$ & $\begin{array}{l}51 \\
(52 \cdot 5)\end{array}$ & $\begin{array}{l}54 \\
(52 \cdot 5)\end{array}$ & $\begin{array}{l}0.086 \\
\text { (1) }\end{array}$ & $>0.7$ \\
\hline A45 & $\begin{array}{c}100 / 115 \\
(100 / 115)\end{array}$ & $\begin{array}{c}100 / 100 \\
(100 / 115)\end{array}$ & $\begin{array}{c}79 \\
(78 \cdot 75)\end{array}$ & $\begin{array}{c}26 \\
(26 \cdot 25)\end{array}$ & $\begin{array}{l}0.003 \\
(1)\end{array}$ & $>0.9$ \\
\hline
\end{tabular}

${ }^{a}$ From gel phenotype.

${ }^{b}$ From observed segregation.

${ }^{c}$ Not distinguishable.

(ii) Joint segregation

Despite emphasis being placed on single locus segregation analyses, careful planning of selected crosses permitted a limited investigation of linkage relationships between loci. A total of 49 different pairwise examinations of loci were possible, though in many cases analysis was restricted to a single family. A summary of the joint segregation analyses undertaken is presented in table 7, employing the format of May et al., (1980). Nonrandom assortment (indicated by shaded cells in table 7) was detected for four loci combinations. The linkage phase for all combinations of loci examined was unknown. Therefore it was not possible to discriminate conclusively between classical linkage and pseudolinkage.

Based on their own extensive experience in the study of joint segregation in salmonids, May et al., (1979b), and again later May et al., (1980), warn of the pitfalls involved in inferring positive linkage between loci based on non-random chi-square values of low significance, especially where data is restricted to a single cross. Such results can be due to the vagaries of the chi-square test itself or due to the occurrence of a singular meiotic anomaly within that family.

Two cases of non-random association detected in this study may fall into the above category, namely between Dia and Pgi- 2 and between ${ }_{s}$ Mdh-3,4 and Pgi-2. In both cases the significance level was low, $0.01<\boldsymbol{P}<$ 0.05 . The joint segregation analyses for both these loci combinations are given in table 8 . In the case of Dia and Pgi-2 only a single family was available for analysis. No comparable test for linkage association between these loci in other salmonids has been reported. Of the six comparisons made between ${ }_{s}$ Mdh-3,4 and Pgi-2, only on one occasion (involving the 
TABLE 6

Summary of informative crosses for ${ }_{s}$ Aat-4, Dia, G3p-2, ${ }_{s} I d h-1,{ }_{s} I d h-2$, Ldh-5, ${ }_{s}$ Mdh-2, Pgi-2 and Pgi-3 including G-test analyses for Mendelian segregation of alleles. Unless otherwise indicated all individual crosses within pooled results were found to segregate according to Mendelian expectations

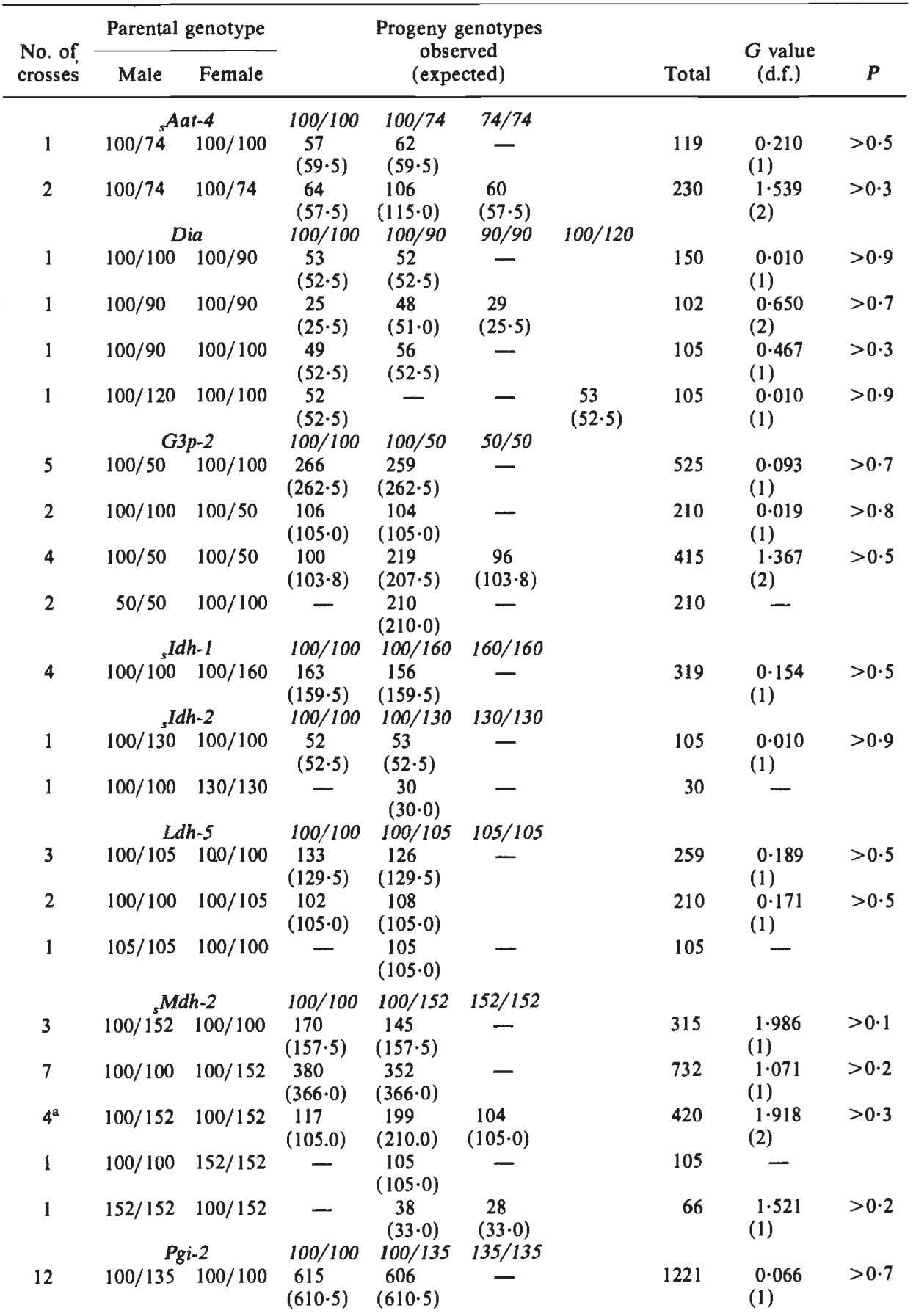


TABLE 6 (continued)

\begin{tabular}{|c|c|c|c|c|c|c|c|c|}
\hline \multirow{3}{*}{$\begin{array}{c}\text { No. of } \\
\text { crosses }\end{array}$} & \multicolumn{2}{|c|}{ Parental genotype } & & \multirow{2}{*}{\multicolumn{2}{|c|}{$\begin{array}{c}\text { Progeny genotypes } \\
\text { observed } \\
\text { (expected) }\end{array}$}} & \multirow{3}{*}{$\begin{array}{r}\text { Total } \\
105\end{array}$} & \multirow{3}{*}{$\begin{array}{c}G \text { value } \\
\text { (d.f.) }\end{array}$} & \multirow{3}{*}{$\begin{array}{c}P \\
>0 \cdot 1\end{array}$} \\
\hline & \multirow{2}{*}{$\begin{array}{c}\text { Male } \\
100 / 100\end{array}$} & \multirow{2}{*}{$\begin{array}{l}\text { Female } \\
100 / 135\end{array}$} & & & & & & \\
\hline & & & $\begin{array}{c}45 \\
(52 \cdot 5)\end{array}$ & $\begin{array}{l}60 \\
(52 \cdot 5)\end{array}$ & - & & & \\
\hline 2 & $100 / 135$ & $100 / 135$ & $\begin{array}{c}48 \\
(52 \cdot 5)\end{array}$ & 111 & $\begin{array}{c}51 \\
(52 \cdot 5)\end{array}$ & 210 & $\begin{array}{l}0.777 \\
(2)\end{array}$ & $>0.5$ \\
\hline 1 & $100 / 100$ & $135 / 135$ & - & $\begin{array}{c}105 \\
(105 \cdot 0)\end{array}$ & - & 105 & - & \\
\hline & & $i-3$ & $100 / 100$ & $100 / 110$ & $110 / 110$ & & & \\
\hline 4 & $100 / 110$ & $100 / 100$ & $\begin{array}{l}226 \\
(217 \cdot 5)\end{array}$ & $\begin{array}{l}209 \\
(217 \cdot 5)\end{array}$ & - & 435 & $\begin{array}{l}0.665 \\
(1)\end{array}$ & $>0.3$ \\
\hline 4 & $100 / 100$ & $100 / 110$ & $\begin{array}{c}205 \\
(210 \cdot 0)\end{array}$ & $\begin{array}{c}215 \\
(210 \cdot 0)\end{array}$ & - & 420 & $\begin{array}{l}0.238 \\
\text { (1) }\end{array}$ & $>0.5$ \\
\hline 2 & $100 / 110$ & $100 / 110$ & $\begin{array}{l}58 \\
(50 \cdot 75)\end{array}$ & $\begin{array}{c}99 \\
(101 \cdot 5)\end{array}$ & $\begin{array}{l}46 \\
(50 \cdot 75)\end{array}$ & 203 & $\begin{array}{l}1 \cdot 511 \\
(2)\end{array}$ & $>0.3$ \\
\hline
\end{tabular}
0.05 .

a One cross showed statistically significant deviation from Mendelian expectations $G_{2}=6.94, P<$

\section{TABLE 7}

Summary of pairwise comparisons of loci examined for joint segregation in brown trout. Numbers in boxes represent the number of families examined, shaded boxes indicating significant departures $(P<0.05)$ from random assortment

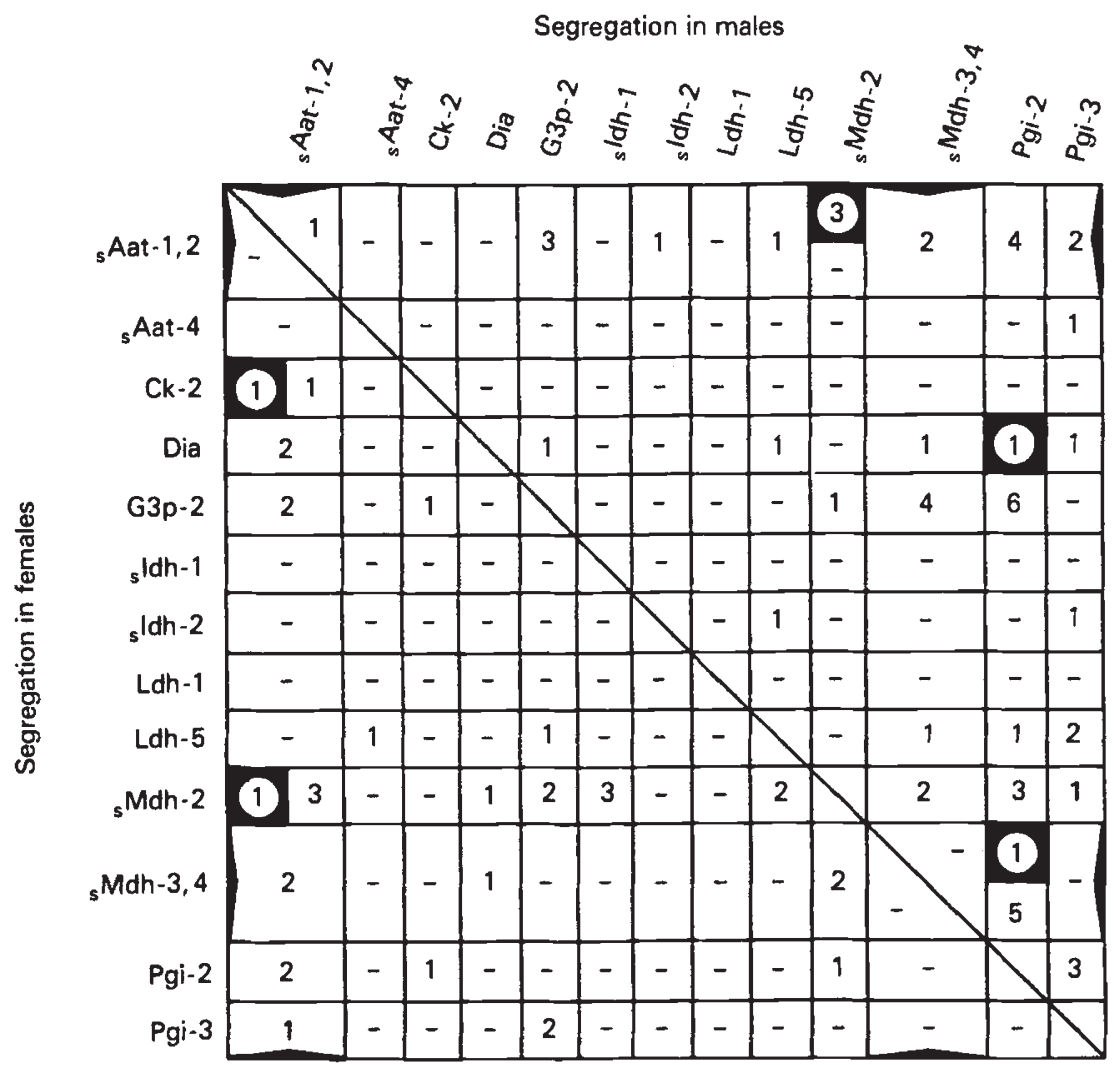




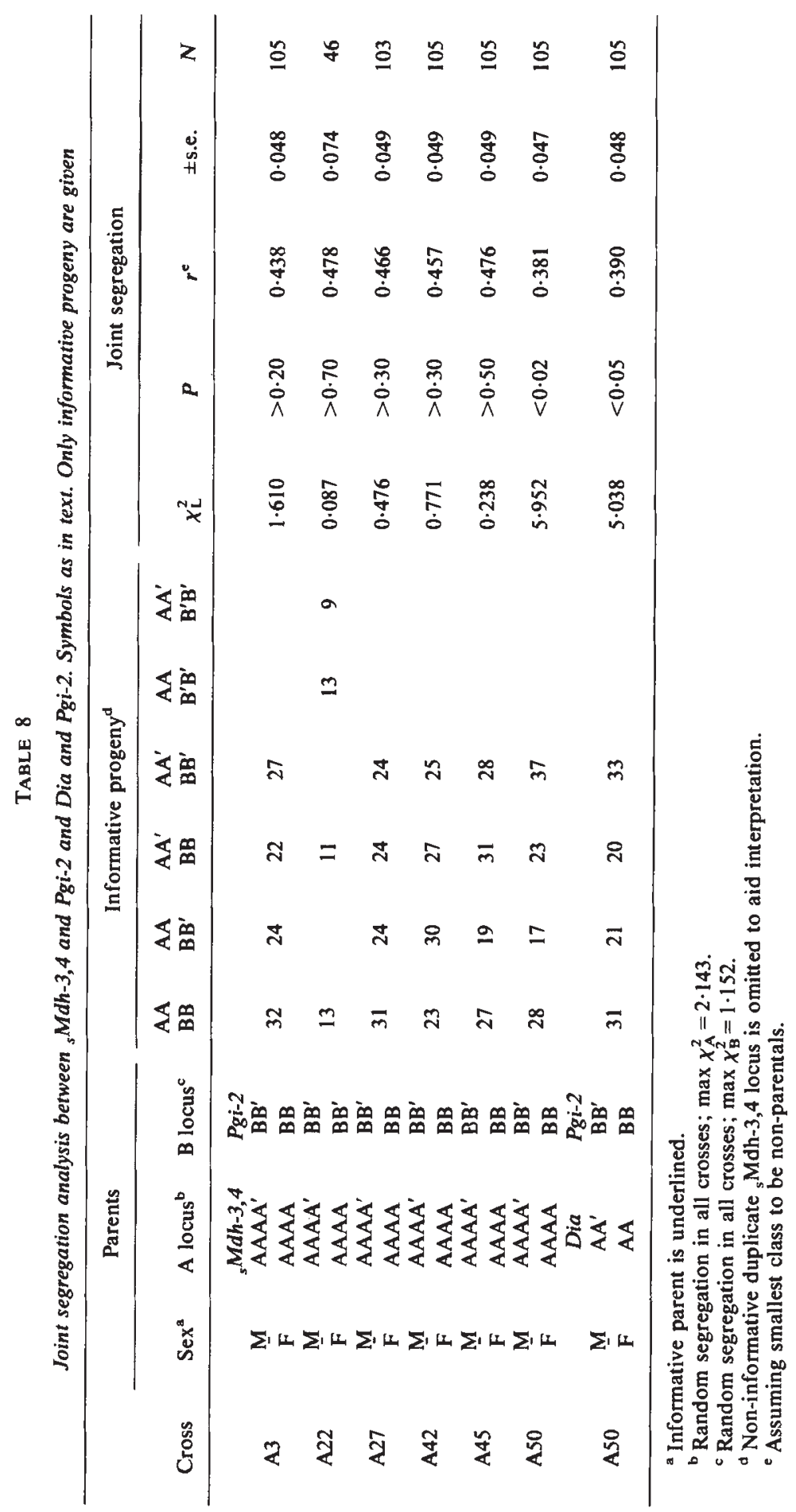




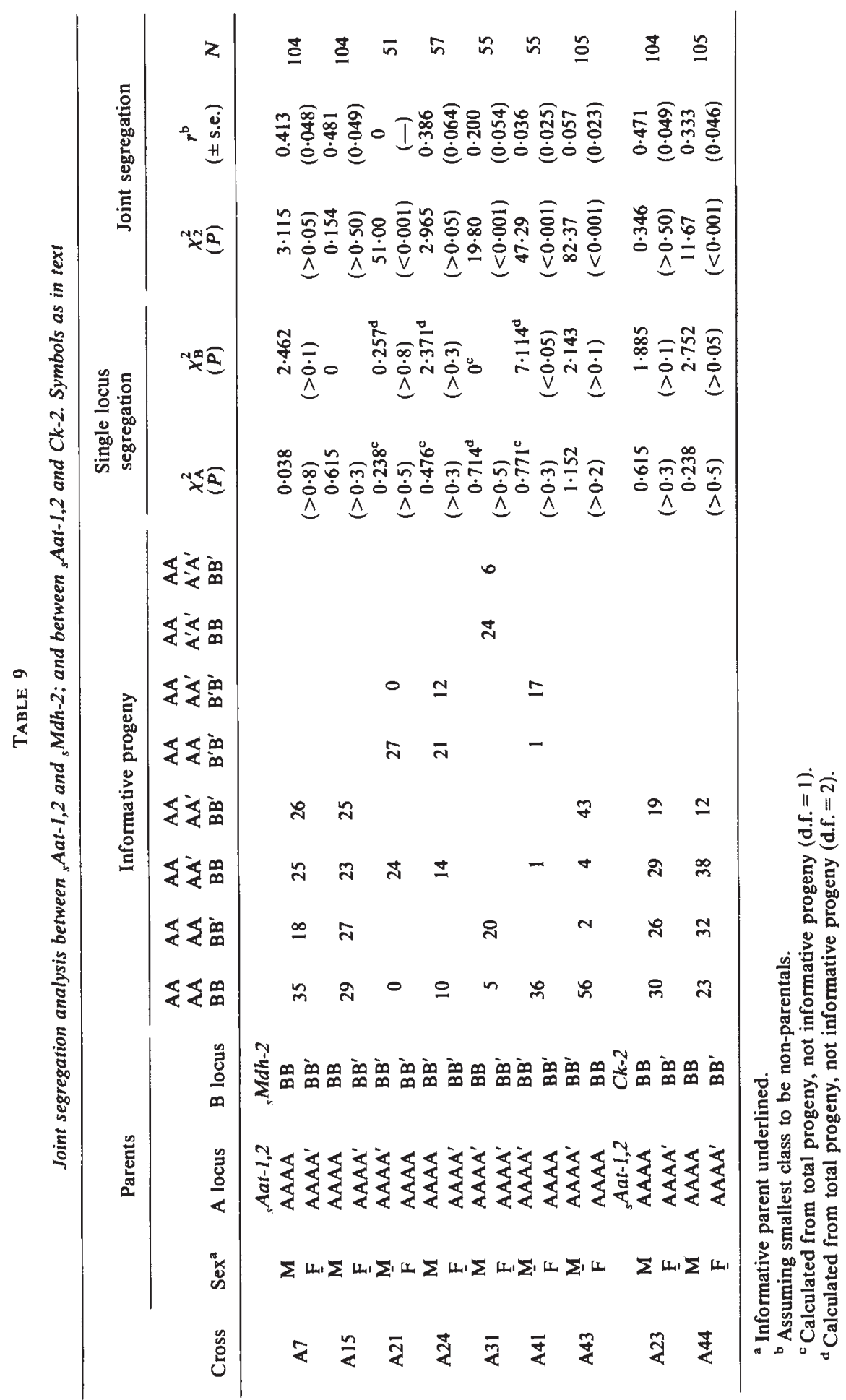


same informative parent as exhibited the Dia/Pgi-2 linkage association) was there evidence of non-random assortment. In this instance a random statistical departure or atypical meiotic segregation in this one family appears to be a likely explanation. However, equally plausible from the limited data available is that the anomalous result reflects true non-random assortment between Pgi-2 and one of the duplicate loci of ${ }_{s} \mathrm{Mdh}-3,4$ while the other five comparisons involved allelic variants for the other duplicate locus of ${ }_{5} \mathrm{Mdh}-3,4$, which is not linked with Pgi-2. Only a single examination between ${ }_{s}$ Mdh-3,4 and Pgi-2 in other salmonids is cited (May et al., 1980), for Salvelinus, which were found to segregate at random. A similar single observation was noted between ${ }_{s} \mathrm{Mdh}-3,4$ and Pgi-1 in the same study.

Two other linkage associations, this time highly significant $(P<0.001)$, were observed, both involving ${ }_{s}$ Aat-1,2, detailed in table 9 . Two comparisons between ${ }_{s} \mathrm{Aat}-1,2$ and $\mathrm{Ck}-2$, both involving female informative parents, revealed one case of random assortment $(P>0.5)$, the other exhibiting highly significant non-random assortment $(P<0.001)$. This is thought likely to reflect a linkage association between $\mathrm{Ck}-2$ and one of the duplicate pair of ${ }_{s}$ Aat-1,2 loci, the other case presumably reflecting a test between Ck-2 and the alternate locus.

Non-random assortment between ${ }_{s} A a t-1,2$ and ${ }_{s} \mathrm{Mdh}-2$ was recorded for all three male, and one of four female informative parents examined. Again very strong linkage $(P<0.001)$ for four out of seven comparisons would suggest that both ${ }_{s}$ Aat-1,2 loci were investigated, ${ }_{s} \mathrm{Mdh}-2$ being linked to only one of them. Average recombination frequency $(\bar{r})$ for the males was 0.031 , one male showing no recombination at all (cross A21), and for the female was $0 \cdot 20$, indicating very tight linkage between these loci. These results are in agreement with similar observations for Salvelinus by May et al., (1980) who report a consistently greater degree of recombination among females than among males. No comparable studies between ${ }_{s} A a t-1,2$ and ${ }_{s} \mathrm{Mdh}-2$ (or the paralogous locus ${ }_{s} \mathrm{Mdh}-1$ ) have been reported for Salmo though this linkage association has been explored in Salvelinus (May et al., 1980). Non-random assortment was reported between ${ }_{s} A a t-1,2$ and ${ }_{s}$ Mdh-1 in all four comparisons made. In each case, the informative parent was made, no comparisons being available for females. To conform with the nomenclature adopted by May et al., (1980) the ${ }_{s}$ Mdh-2 linked ${ }_{s}$ Aat locus has been likewise designated ${ }_{s}$ Aat-1, (purely on an arbitrary basis) and the alternate locus termed ${ }_{\mathrm{s}}$ Aat -2 .

All other pairwise examinations of brown trout loci were found to be in random association. These included combinations for which non-random association have been observed (in at least one lot) between orthologous loci (or metalogous) in other salmonids. These are: ${ }_{s}$ Aat-1,2 and G3p-1, ${ }_{\mathrm{s}}$ Aat-1,2 and ${ }_{\mathrm{s}}$ Mdh-3,4, ${ }_{\mathrm{s}}$ Mdh-1 and G3p-1 in Salvelinus (May et al., 1980). Furthermore this study confirmed random association between ${ }_{s} \mathrm{Mdh}-2$ and Dia in brown trout, first reported by May et al., (1979a) and between ${ }_{\mathrm{s}} \mathrm{Mdh}-2$ and G3p-2 (May, 1980). The two other pairwise combinations for brown trout loci cited in the latter report involved ${ }_{\mathrm{s}} \mathrm{Mdh}-1$ with ${ }_{\mathrm{s}} \mathrm{Mdh}-2$ and ${ }_{\mathrm{s}} \mathrm{Mdh}-1$ with G3p-2. These were not studied during this investigation ${ }_{s} \mathrm{Mdh}-1$ not being polymorphic in Irish brown trout.

\section{Discussion}

Most studies of electrophoretic variation have not involved breeding data, with interpretation based on a combination of other criteria such as 
the banding pattern being consistent with the known quaternary structure of the enzyme, conformance with Hardy-Weinberg expectations, and consistency of expression under different electrophoretic conditions and in different tissues (detailed by Utter et al., 1974; Allendorf and Utter, 1979). With the recent confirmation in this laboratory (Henry, 1984) of Mendelian inheritance for the Ldh-1(n) variant allele recorded for Irish brown trout, inheritance studies have, without exception, verified the proposed genetic interpretations for all polymorphic loci described by Taggart et al., (1981a). The three recorded departures from Mendelian segregation most likely represent random statistical deviations among the 119 tests performed. The apparent accuracy of genetic hypotheses based on properly analysed electrophoretic results other than breeding data, as established through this and other studies, increases the confidence with which the results and conclusions of many investigations which lack definitive inheritance studies can be viewed. Of course, there is no substitute for inheritance studies in the final analysis of the genetic basis of electrophoretic polymorphism. Indeed in this investigation such studies have revealed an additional allele, Dia(120), the presence of artefact bands having led, previously, to the dismissal of a genetic basis for the observed zymogram variation. Breeding data are also the only way to establish whether inheritance is disomic or tetrasomic (Allendorf et al., 1975). In agreement with previous studies for other salmonid species, inheritance in the brown trout is shown to be almost exclusively disomic. The single aberrant progeny phenotype observed for ${ }_{\mathrm{s}}$ Aat-1,2 (A23), however, may be indicative of residual tetrasomy (May et al., 1979b).

Single locus segregation studies are also of importance as potential indicators of the reliability and limitations of electrophoretic data obtained for certain loci. For example, although the difficulty in discriminating between Ck-2(100/100) and Ck-2(100/115) phenotypes has been recognised in the past (Allendorf et al., 1976; Utter et al., 1979; Taggart et al., 1981a) the degree of apparent mistyping reported in this study was surprisingly large, considering the particularly detailed attention given to screening broodstock. Similar discriminatory difficulties were encountered for allozyme variation at ${ }_{s} \mathrm{Mdh}-3,4$. In contrast, the results of breeding studies confirmed the correct typing of all ${ }_{s}$ Aat-1,2 parental phenotypes, despite this being based, in many cases, solely on differential staining intensities of bands.

Although limited in scope, the joint segregation data presented here for the brown trout provide a number of interesting details. Of the four putative linkage associations identified, only in the case of ${ }_{s} \mathrm{Aat}-1,2$ with ${ }_{s} \mathrm{Mdh}-2$ were multiple comparisons possible. Coincidently the ${ }_{s}$ Aat-1- ${ }_{s}$ Aat-2- $\mathrm{Mdh}-2$ linkage grouping has been extensively investigated for other salmonids (Allendorf and Utter, 1976; May et al., 1980; Wright et al., 1980).

Wright et al., (1980) have developed, and recently expanded (Wright $e$ t al., 1983), a chromosomal model to relate the occurrence of both classical linkage and pseudolinkage among ${ }_{s} A a t-(1,2), \operatorname{Mdh}-(1,2)$ and G3p-1 (presumed to be orthologous with G3p-2 in the brown trout) with cytological observations of salmonid chromosomes. An ancestral fusion of a nonhomologous acrocentric chromosome (carrying the G3p-1 locus) to one of an original pair of homologous acrocentrics (each carrying a distally situated ${ }_{s}$ Aat locus and a proximally situated ${ }_{\mathrm{s}} \mathrm{Mdh}$ locus) is postulated, homeologous multivalent pairing of these chromosomes accounting for the observed forms of residual tetrasomy (see Wright et al, 1983 for a detailed consideration). 
Though based primarily on Salvelinus data, as yet limited investigations of brown trout by these workers suggests an identical model for this species.

The detection of a highly statistically significant linkage association between ${ }_{5}$ Aat-1,2 and ${ }_{s}$ Mdh-2 in this study is in agreement with the above model. The single observation of nonrandom assortment for a female would suggest classical linkage in this case while classical linkage or pseudolinkage may account for the linkage associations detected for the three males. Both classical linkage and pseudolinkage between ${ }_{s} A$ at $-1,2$ and ${ }_{s} \mathrm{Mdh}-1$ have been reported for Salvelinus hybrids (May et al., 1980) indicating conservation of this linkage association between salmonid genera. Further, but more tentative, evidence for the model is the observation of a single aberrant progeny phenotype for cross A23. Such a phenotype would be predicted by homeologous multivalent pairing of the chromosomes followed by crossover between the ${ }_{s}$ Aat locus and the centromere. On the other hand, pseudolinkage between ${ }_{s}$ Aat- 1 and ${ }_{s} A a t-2$ would be expected in male brown trout. The single family tested (informative male), however, showed random assortment between these loci $\left(\chi_{\mathrm{L}}^{2}=0.263, P>0.5\right)$. Similarly, the model predicts either classical linkage or pseudolinkage between G3p-2 and ${ }_{s}$ Mdh-2 (depending on which chromosome ${ }_{s}$ Mdh-2 is situated) and both classical linkage and pseudolinkage between G3p-2 and ${ }_{s}$ Aat-1,2. Again all these combinations were examined and found to segregate at random.

While these results may suggest a different chromosomal arrangement between Salvelinus and $S$. trutta a number of other explanations could account for these discrepancies. Considering the somewhat limited data available, the probability of detecting pseudolinkage between loci may be low. The occurrence of pseudolinkage requires preferential homeologous pairing of chromosomes at meiosis which, theoretically, should be more common among genomes of diverse origin (see Wright et al., 1983). This agrees with the observation of the more frequent occurrence of pseudolinkage among splake (hybrid) trout than for pure strains of brook trout or rainbow trout. Thus statistical evidence of pseudolinkage for the relatively genetically homogeneous brown trout stocks examined in this study would probably require the screening of a much greater number of both families and progeny per family than was actually undertaken. A similar argument can be extended for the failure to detect the predicted classical linkage associations. With ${ }_{s} A$ at -1 or 2 and G3p-2 being distantly separated on opposing arms of a metacentric (according to the model) only a weak linkage association is to be expected, the recombination frequency probably approaching $0 \cdot 5$. To a lesser extent this may also apply to the failure to detect classical linkage between ${ }_{5} \mathrm{Mdh}-2$ and $\mathrm{G} 3 \mathrm{p}-2$. (Note that this argument further decreases the likelihood of detecting pseudolinkage between these combinations of loci as well). Alternatively, in the specific cases investigated in this study the polymorphic informative ${ }_{s}$ Aat or ${ }_{s} \mathrm{Mdh}$ locus may have been situated on the acrocentric chromosome of the homeologous pair and thus classical linkage with G3p-2 (by definition on the metacentric chromosome) would no longer be predicted.

The singular observation of a possible linkage association between ${ }_{s}$ Aat-1,2 and Ck-2 for the brown trout has not previously been reported for any other salmonid species. May et al., (1980) report random association between ${ }_{s}$ Aat-1,2 and $\mathrm{Ck}-1$ in the splake trout. However, as the degree of homology between the $\mathrm{Ck}$ loci in these two "species" (i.e., whether 
orthologous or paralogous) is unknown, these results are not necessarily contradictory. While the linkage association between ${ }_{\mathrm{s}} \mathrm{Aat}-1,2$ and $\mathrm{Ck}-2$ was highly statistically significant and indicative of classical linkage, the informative parent being female, the singular occurrence of an atypical chromosomal polymorphism cannot be ruled out, without further replicates. However, it is interesting to speculate on the possible position of $\mathrm{Ck}-2$ in relation to the other loci identified in this linkage grouping. Random association between Ck-2 and G3p-2 was noted in the single comparison examined which tentatively suggests that these loci are not on the same chromosome arm. This would place Ck-2 on the same chromosome arm as ${ }_{s}$ Aat- 1 or 2 and ${ }_{s} \mathrm{Mdh}-1$ or 2 . The higher recombination frequency observed between ${ }_{s}$ Aat-1,2 and Ck-2 than between ${ }_{s}$ Aat-1,2 and ${ }_{s} \mathrm{Mdh}-2$ would indicate that Ck-2 possibly lies between ${ }_{s} \mathrm{Mdh}-1$ or 2 and the centromere. Examination of joint segregation data between Ck-2 and ${ }_{s} \mathrm{Mdh}-2$ may resolve whether both loci are linked to ${ }_{s} \mathrm{Aat}-1$ or whether Ck-2 is linked to the alternative locus ${ }_{s}$ Aat-2. The former model would predict tight classical linkage to be detected between Ck-2 and ${ }_{s} \mathrm{Mdh}-2$, while in the latter case, at most, weak pseudolinkage would be postulated.

The salmonids present a unique, attainable, opportunity to study many aspects of the underlying mechanisms involved in evolution by gene duplication. The extensive linkage studies reported for the hybridised Salvelinus genome summarised by May et al., (1980) form a sound foundation on which to base additional studies of other salmonid species. However, while the ideal hybridised genome of the splake trout enables a large number of pairwise comparisons of loci to be examined, there is much more limited scope among pure salmonid species. As genetic variation among hatchery strains may be restricted, attention must turn to utilising the polymorphisms found in natural populations (May et al., 1980). It is therefore likely that extensive investigations of linkage associations within and among salmonid genera will tend to rely more on the efforts of a number of independent research groups, as many observed polymorphisms have only a relatively localised occurrence. It is felt that by employing (and modifying) the methodology described for this study, which incurs only relatively limited demands on both time and hatchery/rearing facilities, additional inheritance studies could be encouraged on more regional bases.

Acknowledgements. We are indebted to the Department of Agriculture, N. Ireland for the provision of broodstock and rearing facilities; especially to the manager, G. O'Neill, and staff of Movanagher Fish Farm for their technical advice and for the maintenance of fish. We thank our colleagues C. Fleming and T. Henry for assistance in the performing of crosses. We are also grateful to Dr B. May for commenting on a preliminary draft of this paper. The award of a post-graduate studentship to J.B.T. by the Department of Agriculture, N. Ireland is gratefully acknowledged. Later work was supported by NERC.

\section{REFERENCES}

ALLENDORF, F. W. 1975. Genetic variability in a species possessing extensive gene duplication: Genetic interpretation of duplicate loci and examination of genetic variation in populations of rainbow trout. Ph.D. Thesis. University of Washington, Seattle.

ALLENDORF, F. W. AND PHELPS, S. R. 1981. Isozymes and the preservation of genetic variation in salmonid fishes, In N. Ryman (ed.), Fish Gene Pools, Ecol. Bull. (Stockholm), 34, 37-52. 
ALLENDORF, F. W. AND UTTER, F. M. 1973. Gene duplication within the family Salmonidae: Disomic inheritance of two loci reported to be tetrasomic in rainbow trout. Genetics, 74, 647-654.

ALLENDORF, F. W. AND UTTER, F. M. 1976. Gene duplication in the family Salmonidae: III. Evidence of linkage between two duplicated loci coding for aspartate aminotransferase in cutthroat trout. Hereditas, 82, 19-24.

AllendoRF, F. W. AND UTTER, F. M. 1979. Population genetics, In W. S. Hoar, D. J. Randall and J. R. Brett (eds.), Fish Physiology, Vol. VIII, pp. 407-454, Academic Press, London.

ALLENDORF, F. W., UTTER, F. M. AND MAY, B. P. 1975. Gene duplication within the family Salmonidae: II. Detection and determination of the genetic control of duplicate loci through inheritance studies and the examination of populations, In C. L. Markert (ed.), Isozymes, Vol. IV, pp. 415-432, Academic Press, London.

ALLENDORF, F. W., RYMAN, N., STENNEK, A. AND STÅHL, G. 1976. Genetic variation in Scandinavian brown trout (Salmo trutta L.): evidence of distinct sympatric populations. Hereditas, 83, 73-82.

ALLENDORF, F. W., MITCHELL, N., RYMAN, N. AND STÅHL, G. 1977. Isozyme loci in brown trout (Salmo trutta L.): detection and interpretation from population data. Hereditas, 86 , 179-190.

ALLENDORF, F. W., KNUDSEN, K. L. AND PHELPS, S. R. 1982. Identification of a gene regulating the tissue expression of a phosphoglucomutase locus in the rainbow trout. Genetics, 102, 259-268.

AMEND, D. AND SMITH, L. 1974. Pathophysiology of infectious hematopoietic necrosis virus disease in rainbow trout (Salmo gairdneri): early changes in blood and aspects of the immune response after injection of IHN virus. J. Fish. Res. Bd Can., 31, 1371-1378.

ASPINWALL, N. 1974. Genetic analysis of duplicate malate dehydrogenase loci in the pink salmon, Oncorhynchus gorbuscha. Genetics, 76, 65-72.

BAILEY, G. S., Wilson, A. C., HALVER. J. E. AND JOHNSON, C. L. 1970. Multiple forms of supernatant malate dehydrogenase in salmonid fishes. J. biol. Chem., 245, 5927-5940.

CLAYTON, J. W., FRANZIN, W. G. AND TRETIAK, D. N. 1973. Genetics of glycerol-3-phosphate dehydrogenase isozymes in white muscle of lake whitefish (Coregonus clupeaformis). $J$. Fish. Res. Bd. Can., 30, 187-193.

CLAYTON, J. W., TRETIAK, D. N., BILLECK, B. N. AND IHSSEN, P. 1975. Genetics of multiple supernatant and mitochondrial malate dehydrogenase isozymes in rainbow trout (Salmo gairdneri), In C. L. Markert (ed.), Isozymes, Vol. IV, pp. 433-448, Academic Press, London.

DAVISSON, M. T., WRIGHT, J. E. AND ATHERTON, L. M. 1973. Cytogenetic analysis of pseudolinkage of LDH loci in the teleost genus Salvelinus. Genetics, 73, 645-658.

ENGEL, W., SCHMIDTKE, J. AND WOLF, U. 1971. Genetic variation of $\alpha$-glycerophosphatedehydrogenase isoenzymes in clupeoid and salmonoid fish. Experientia, 27, 1489-1491.

FERGUSON, A. 1980. Biochemical Systematics and Evolution. Blackie, Glasgow.

FERGUSON. A. AND MASON, F. M. 1981. Allozyme evidence for reproductively isolated sympatric populations of brown trout (Salmo trutta L.) in Lough Melvin, Ireland. J. Fish Biol., 18, 629-642.

FERGUSON, A. AND FLEMING, C. C. 1983. Evolutionary and taxonoinic significance of protein variation in the brown trout (Salmo trutta L.) and other salmonids, In G. S. Oxford and D. Rollinson (eds.), Protein Polymorphism: Adaptive and Taxonomic Significance, pp. 86-99, Academic Press, London.

GUYOMARD, R. AND KRIEG, F. 1983. Electrophoretic variation in six populations of brown trout (Salmo trutta, L.). Can. J. Genet. Cytol., 25, 403-413.

HART, P. J. B. AND PITCHER, T. J. 1969. Field trials of fish marking using a jet inoculator. $J$. Fish Biol., 1, 383-385.

HENRY, T. 1984. Lactate dehydrogenase and phosphoglucose isomerase isozymes and allozymes of the brown trout (Salmo trutta L). Ph.D. Thesis. The Queen's University of Belfast.

MATHER, K. 1951. The Measurement Of Linkage In Heredity. Methuen, London.

MAY, B. 1980. The salmonid genome: evolutionary restructuring following a tetraploid event. Ph.D. Thesis. The Pennsylvania State University, State College.

MAY,B., UTTER, F. M. AND ALLENDORF, F. W. 1975. Biochemical genetic variation in pink and chum salmon: inheritance of intraspecies variation and apparent absence of interspecies introgression following massive hybridization of hatchery stocks. J. Heredity, 66 , 227-232.

MAY, B., STONEKING, M. AND WRIGHT, J.E. 1979a. Joint segregation of malate dehydrogenase and diaphorase loci in brown trout (Salmo trutta). Trans. Am. Fish. Soc., 108, 373-377.

MAY, B., WRIGHT, J. E. AND STONEKING, M. 1979b. Joint segregation of biochemical loci in Salmonidae; results from experiments with Salvelinus and review of the literature on other species. J. Fish. Res. Bd. Can., 36, 1114-1128. 
MAY, B., STONEKING, M. AND WRIGHT, J. E. 1980. Joint segregation of biochemical loci in Salmonidae. II. Linkage associations from a hybridized Salvelinus genome ( $S$. namaycush $\times$ S. fontinalis). Genetics, 95, 707-726.

MAY, B., WRIGHT, J. E. AND JOHNSON, K. R. 1982. Joint segregation of biochemical loci in Salmonidae. III. Linkage associations in Salmonidae including data from rainbow trout (Salmo gairdneri). Biochem. Genet., 20, 29-40.

OHNO, S. 1970. Evolution by Gene Duplication. Allen and Unwin, London.

OHNO, S. M., MURAMOTO, J., KLEIN, J. AND ATKIN, N. B. 1969. Diploid-tetraploid relationship in clupeoid and salmonoid fishes, In C. D. Darlington and K. R. Lewis (eds.), Chromosomes Today, Vol. II, pp. 139-147, Oliver and Boyd, Edinburgh.

PERRIARD, J. C., SCHOLL, A. AND EPPENBERGER, H. M. 1972. Comparative studies on creatine kinase isozymes from skeletal-muscle and stomach of trout. J. Exp. Zool, 182, 119-126.

REINITZ, G. L. 1977. Inheritance of muscle and liver types of supernatant NADP-dependent isocitrate dehydrogenase in rainbow trout (Salmo gairdneri). Biochem. Genet., 15, 445-454.

ROPERS, H.-H., ENGEL, W. AND WOLF, U. 1973. Inheritance of the S-form of NADP-dependent isocitrate dehydrogenase polymorphism in rainbow trout, In J. H. Schröder (ed.), Genetics and Mutagenesis of Fish, pp. 319-327, Springer-Verlag, Berlin.

RYMAN, N. AND STÅHL, G. 1980. Genetic changes in hatchery stocks of brown trout (Salmo trutta). Can. J. Fish. Aquat. Sci., 37, 82-87.

RYMAN, N, AND STÅHL, G. 1981. Genetic perspectives of the identification and conservation of Scandinavian stocks of fish. Can. J. Fish. Aquat. Sci., 38, 1562-1575.

RYMAN, N., ALLENDORF, F. W. AND STÅHL, G. 1979. Reproductive isolation with little genetic divergence in sympatric populations of brown trout (Salmo trutta). Genetics, 92, 247-262.

SCHMIDTKE, J., ZENZES, M. T., WEILER, C., BROSS, K. AND ENGEL, W. 1976a. Gene action in fish of tetraploid origin. IV. Ribosomal DNA amount in clupeoid and salmonoid fish. Biochem. Genet., 14, 293-297.

SCHMIDTKE, J., SCHULTE, B., KUHL, P. AND ENGEL, W. $1976 b$. Gene action in fish of tetraploid origin. V. Cellular RNA and protein content and enzyme activities in cyprinid, clupeoid, and salmonoid species. Biochem. Genet., 14, 975-980.

STÅHL, G. 1980. Genetic variation in two closely related salmonids, brown trout (Salmo trutta) and Atlantic salmon (Salmo salar): a comparison of variability patterns and some management considerations. Ph.D. Thesis. University of Stockholm, Sweden.

STÅHL, G. AND RYMAN, N. 1982. Simple Mendelian inheritance at a locus coding for $\alpha$ glycerophosphate dehydrogenase in brown trout (Salmo trutta). Hereditas, 96, 313-315.

STONEKING, M., MAY, B. AND WRIGHT, J, E. 1979. Genetic variation, inheritance and quaternary structure of malic enzyme in brook trout (Salvelinus fontinalis). Biochem. Genet., 17, $599-619$.

STONEKING, M., MAY, B. AND WRIGHT, J. E. 1981. Loss of duplicate gene expression in salmonids: Evidence for a null allele polymorphism at the duplicate aspartate aminotransferase loci in brook trout (Salvelinus fontinalis). Biochem. Genet., 19, 1063-1077.

TAGGART, J. B. 1981. An electrophoretic study of genetic variation in Irish brown trout (Salmo trutta L.). Ph.D. Thesis. The Queen's University of Belfast.

TAGGART, J., FERGUSON, A. AND MASON, F. M. $1981 a$. Genetic variation in Irish populations of brown trout (Salmo trutta L.): Electrophoretic analysis of allozymes. Comp. Biochem. Physiol., 69B, 393-412.

TAGGART, J., FLEMING, C. AND FERGUSON, A. 1981 b. Additional creatine kinase loci in the brown trout, Salmo trutta L. Isozyme Bulletin, 14, 53-54.

UTHE, J. F. 1971. A simple field technique for obtaining small samples of muscle from living fish. J. Fish. Res. Bd. Can., 28, 1203-1204.

UTTER, F. M., HODGINS, H. O. AND ALLENDORF, F. W. 1974. Biochemical genetic studies of fishes: Potentialities and limitations, In D. C. Malins and J. R. Sargent (eds.), Biochemical and Biophysical Perspectives in Marine Biology, Vol. 1, p. 213-238, Academic Press, New York.

UTTER, F, M., ALLENDORF, F. W. AND MAY, B. 1979. Genetic basis of creatine kinase isozymes in sketetal muscle of salmonid fishes. Biochem. Genet., 17, 1079-1091.

WRIGHT, J. E., MAY, B., STONEKING, M. AND LEE, G. M. 1980. Pseudolinkage of the duplicate loci for supernatant aspartate aminotransferase in brook trout, Salvelinus fontinalis. $J$. Heredity, 71, 223-228.

WRIGHT, J. E., JOHNSON, K., HOLLISTER, A. AND MAY, B. 1983. Meiotic models to explain classical linkage, pseudolinkage, and chromosome pairing in tetraploid derivative salmonid genomes, In M. C. Rattazzi, J. G. Scandalios and G. S. Whitt (eds.), Isozymes: Current Topics in Biological and Medical Research, Vol. 10, p. 239-260, Alan R. Liss, New York. 